\title{
ПОЛІТОЛОГІЯ
}

UDC 32:(351+37.01)

DOI: https://doi.org/10.21564/2075-7190.48.224807

Panfilov Oleksandr Yuriiovych, Doctor of Philosophical Sciences, Professor, Department of Sociology and Political Science,

Yaroslav Mudryi National Law University, Kharkiv, Ukraine

e-mail: philosophy_ay@ukr.net

ORCID ID: 0000-0002-8997-0120

Savchenko Olga Oleksandrivna, $\mathrm{PhD}$, Associate Professor, Foreign Languages Department, Ivan Kozhedub National Air Force University, Kharkiv, Ukraine e-mail: savolg106@gmail.com

ORCID ID: 0000-0003-0085-7189

\section{EDUCATION AS A FACTOR TO SUPPORT THE NATIONAL SECURITY OF THE STATE}

The article specifies the role of education in supporting the national security of the state. It is substantiated that national security significantly depends on the state of education since it takes on the most important tasks for society to train the elite of society, management personnel, and highly qualified specialists in all sectors of the economy, affects changes in the social structure of society, and forms the political views of young people. The role of education in the development of critical thinking in young people is analyzed, which is especially important in the context of information war.

Keywords: national security, nation, education, educational policy, the intellectual potential of the nation.

Problem setting. Further social, economic, and political changes in society, strengthening the Ukrainian state, marking its place within the civilized world

(C) Panfilov O. Y., Savchenko O. O., 2021 
community are impossible without a fundamental national education system aimed at human well-being, the superior status of culture, and spirituality in society. According to UNESCO estimates, a sufficient level of national well-being, which would meet world standards, can now and in the future be achieved only by the countries where $40-60 \%$ of the working-age population have higher education. At the same time, to ensure that social, economic, and political reforms become irreversible and be implemented in the most positive way, it is recognized that it is necessary to retrain at least $25 \%$ of the adult employable population in a fundamentally new way (it concerns the content, character) [1, p. 114].

Researchers of national security problems, such as O. Dzioban, S. Gordienko, and others, believe that the level of educational development is the most important internal indicator of national security since education provides all members of society with the knowledge access, an opportunity to participate in creating spiritual values, and assimilating cultural achievements. [2, p. 406]. Along with science, education, as an important component of spiritual production, enables a person's self-actualization.

On the other hand, researchers single out several special social functions of education: social protection, which allows a person to enlarge potential social opportunities in professional and personal self-determination, especially under market conditions; humanistic function, which emphasizes educational value aspects within the subject of activity in the subjective-objective terms; urbanistic function, which focuses on the influence of education on migration processes (it is more relevant in the context of higher education); demographic function, which emphasizes the importance of cultural and educational factors in the demographic processes of the state (the composition of the population, life expectancy, marital relations, fertility, and so on); the function of historical inheritance and succession of social experience, which reproduces the nature of relations with the outside world and reflects the diversity of the social and role structure of society $[1, \mathrm{p} .117 ; 3]$.

Thus, it is evident that education contains a powerful potential for supporting the national security of the state being one of its factors.

Recent research and publications analysis. The analysis of recent publications on this topic shows a growing awareness of the fact that education and national security are interrelated. The issues of national security in its various aspects are quite thoroughly studied by many authors, among them are V. Abramov, V. Gorbulin, O. Vlasiuk, V. Gorovenko, A. Datsiuk, O. Dzioban, V. Mandragelya, R. Marutyan, Yu. Melnyk, V. Parakhonskyi, G. Sytnyk, M. Trebin and so on. At the same time, the problem of the role of education in supporting the national security of the state is still insufficiently developed. There is a lack of understanding of the role and place of education in the system of national security, as well as its importance for supporting the national security of Ukraine. 
Paper objective. The goal of the article is to attempt to specify the relationship between the state of the education system and the national security of the state.

Paper main body. Neither social system, nor state can develop well without a system of values that unite their members. A nation that does not have its values becomes an uncontrollable crowd. Educational structures take one of the main places in the development of the value system. More than two millennia ago, Aristotle rightly noted that education is «a function carried out by the state for well-defined and specific purposes» [4, p. 57]. In this regard, it is important to single out those groups of values that play a decisive role in the existence of the Ukrainian state and its national security. Of course, it is common to specify the four «grounds» of statehood - territory, population, resources, and culture. Moreover, in the modern world, the emphasis is shifting more and more to the «non-material» sphere. S. Huntington considers that «in the new world, the main differences between people and nations are not ideological, not political, not economic, but cultural» [5, p. 312]. The concept of culture in this context is closely related to education. S. Gessen, for example, believed that the goals of education are cultural values every person should share, therefore «the task of any education is to involve a person in the cultural values of science, art, morality, law, economy» [6, p. 35]. Domestic and foreign globalists share a general consensus that without a new culture of survival, without innovative training, humanity is destined for failure. Moreover, it is social and cultural relations in the new world that are decisive for other types of relations - ideological, political, economic, military [7, p. 40]. Concerning the safety of cultural development, it should be kept in mind that it is education that is the grounds of culture, it lays its foundations. Serious futurologists of all political trends - from right-wing conservatives to left-wing socialists, from supporters of post-industrialism to theorists of the Club of Rome - agree that it is the educational potential that determines the status of a person in society and the status of nations in the world [8].

Real security, taking into account the progress of world civilization, is determined by the level of development of human resources as the main prerequisite for the creation of its scientific, economic, social, cultural, and spiritual potential. It is the field where, at the beginning of the 21 st century, developed countries and entire regions vie for leadership, and, consequently, the level of their own security, preservation of original development and, ultimately, for the multicultural system, for the diversity of the world community. In the light of these prospects, education and science, their range, level, and quality are becoming the leading, decisive factors in the development and support of national security.

It is necessary to understand that national security cannot be ensured only by educational means, but cannot be guaranteed outside the educational space either. 
The role of education at the present stage of the development of our country is determined by the tasks of transforming Ukraine into a democratic society, into a state governed by the rule of law, a state with a market economy, by the tasks to cope with the threat that Ukraine can lag behind world trends in economic and social development. In this regard, education should be considered as the main priority of society and the state.

New civilizational challenges naturally result in a new «educational boom» in many countries, in a dramatic overhaul in education systems - such countries as the USA and Great Britain, China, Eastern Europe, Southeast Asia, and South America are facing this trend. The educational reforms carried out abroad are focused on the current and future needs of society, the efficient use of resources. Ukraine cannot and should not stay away from such global trends. The domestic education system is designed to back the position of Ukraine among leading countries of the world, its international prestige as a country that has always had a high level of culture, science, and education. This prestige should be expressed not only in public recognition but also in the active export of educational services [9].

The general social and economic crisis that took place in the $90 \mathrm{~s}$ of the last century significantly slowed down positive processes in the sphere of education. The state paid less attention to education, which had to survive on its own, separated from the real needs of the country. This caused serious breaks in the «state-educationsociety» system. Under modern conditions, when the state and society have begun to clarify their priorities, it becomes obvious that education can no longer remain in a state of internal isolation and self-sufficiency. The current education system falls significantly behind the processes taking place in society. Currently, comprehensive and deep modernization of the education system is the most important task of the educational policy of Ukraine, its main strategic trend. Today the approach to education should be changed. In the era of globalization and new technologies, this is not just a social sphere. This is an investment in the future of the country, in the support of its national security, that is a task of the state and society, enterprises, organizations, and citizens [9, p. 165-167]. Education covers all levels of security: society, state, individual. It is quite obvious that the economic and military security of the state is impossible without qualified personnel, while technological security is unsatisfiable without scientific research.

The unbiased analysis of the events that have taken place in recent decades identifies serious threats and challenges to the self-preservation of Ukraine: the population is gradually decreasing, the country's traditional way of spiritual and social life is collapsing, and its national heritage is shrinking. The causes for this are both internal (the lost instinct of self-preservation of the nation) and external (intensification of the struggle for the natural resources of the Earth that are being 
exhausted). The cause for the latter one has become the resource and demographic crisis due to the reluctance of some states to reduce consumption whereas others do not want to slow down the rate of population growth $[2$, p. 473-493; 10]. It is easy to understand that humanity is around the next repartition of the world. The awareness of this threat can contribute not only to reconciliation and unification of the Ukrainian people around the values that are traditional for our country but also to the revival of Ukraine as a state. In other words, the saving of the nation lies in arousing the instinct of its self-preservation, and one of the main directions on the way to this goal should be the improvement of education within the sphere of the national security of Ukraine.

Speaking about the role of education and educational policy in supporting national security, it should be noted that education affects all levels of national security (security of society, state, individual) and all its structural elements. Education is one of the most important components of the national security of any country, and it becomes more important when the level of its development is higher.

However, it can be said that there is a number of threats to the national security of Ukraine in the context of educational policy.

The majority of researchers blame the difficult situation of Ukrainian education on the lack of financial and material support of educational institutions; the family rescue from raising children, the inactivity and unwillingness of young people to get knowledge, abilities, skills; the imperfection of systems for training and retraining of teaching staff; low prestige of the teaching profession and so on $[9 ; 11]$.

Analysing the state of modern Ukrainian education, its marginal aspects should be emphasized: first, the spread of education and its impact on social mobility and life plans of an individual; second, the identification of discrepancies between social strata in the educational sphere and their explanation; third, the description of social systems in educational institutions and the interaction between the teacher and the student; fourth, empirical studies of the efficiency of teaching methods used [3, p. 270-271].

The study of the marginality of Ukrainian higher education is burning due to the collapse of the social and cultural space, the unconfirmed status of higher education graduates, and the unrealized intellectual potential of society.

The analysis of the current marginal situation of higher education should necessarily include the aspect of pre-university education. The social and professional orientation of schoolchildren and the formation of immediate life plans, as well as the first steps towards their implementation when choosing a form of long-life education or direct employment, significantly depend on the social environment within which schoolchildren's worldview is formed, primarily within the family and school. Speaking of social orientation, an individual's awareness of their place in 
the system of social relations is considered. The vocational guidance is considered as the process of an individual's awareness of specific types of labour activity in society - professions, their own preferences and abilities for one (or several) of them, ways or means of mastering the knowledge and skills that are necessary to perform the corresponding functions.

Dramatic changes in the development of social conditions have resulted in the break between education and the living conditions of society, which takes various forms and determines the crisis in education. American scientist P. Coombs, analysing the crisis in education, emphasizes that the most significant causes that contributed to the separation of education from life were: a sharp increase in demand for educational services that the existing schools and universities could not provide; insufficient financing of education; inactive and non-dynamic internal structure of a personality; the inertia of society. To overcome these tendencies, according to P. Coombs, the mutual adaptation of society and education is necessary [12, p. 14].

The recognized authority in the sphere of American moral education, T. Licona sees the cause of the decline of American society in «value neutrality that takes a heavy toll on the spiritual traits of American youth». He states that «education without values does not exist, the only point is what these values are and how to form them to the best advantage. The most important task of an individual's existence is how to live with dignity, and of the whole mankind - how to learn to coexist with one another and with Nature» [13, p. 17].

Unfortunately, the mentioned causes for the crisis in the educational system are also characteristic of Ukrainian society. A peculiarity of our country lies in the fact that the task should be solved in two dimensions: firstly, how to overcome the crisis of the classical model of education in general, which is associated with the understanding of new global realities and tendencies of the twentieth century; and secondly, how to overcome the crisis of the Soviet model of education [12, p. 189-190]. The system of education in the current marginal situation is trying to mobilize its adaptive potential. Therefore, in the modern era, new types of educational institutions appear such as commercial or semi-commercial schools of additional education, lyceums, universities, and colleges that carry out social development, therapy, propaedeutics, and facilitation.

To overcome the crisis, Ukrainian scientists V. Andrushchenko, V. Kremen', V. Lutai, V. Ohnev'iuk and others suggest moving to new educational models, universalization, anthropologism, introducing interdisciplinary educational programs, expanding free choice, using innovative potential in the regional structure, which is especially important in our time $[9 ; 14 ; 15 ; 16]$.

The university education system contains the potential for a radical renovation of the ways of transmitting spirituality, the development of human abilities, and 
innovative trends in modern education make it possible not only to approach the choice of a specialty consciously but also provide an opportunity for retraining (mobile transition to new knowledge based on universal social and humanitarian education).

Today Ukrainian universities are known to have the opportunity to enrol students on a commercial basis. This fact, in our opinion, contributes to social differentiation, which deepens the dissonance created by educational structures of an innovative type. On the one hand, innovations and the commercial benefits of education make it possible to raise the level of education of some young people (mainly from wealthy families), on the other hand, the democratic principle - to give equal chances to all citizens entering life to develop their abilities is violated, while this is a necessary condition for building up the intellectual potential of the country (the most important factor of social progress).

It becomes obvious that the available programs for the elimination of crisis in education are not a sufficient condition for solving the problems of education and the student's personality. A cohesive synthesis of a program of this type and a personality-oriented educational program, adapted to the needs of the individual in the educational system, can be more efficient. The classical educational system, which is based on the concept of mastering knowledge, skills, and abilities in modern conditions, is practically exhausted. The development of a new educational paradigm is taking place - an orientation towards the holistic spiritual and moral development of a person, who is ready for universal activity. The main goal of modernizing education is not only updating its content, but also developing the student's personality, creative abilities, independence, initiative, and striving for self-education. In the context of a new social and cultural paradigm, the goal of development is to meet an individual's need for self-realization through the use of potential abilities for thinking, communication, and work [17].

Currently, an unprecedented social and cultural revolution is taking place, and our country experiences its consequences to the full extent. Today, with the help of the mass media, the idea of eliminating social control is implanted and the advantages of strength and the Western morality of success are cultivated, which means a certain informational and psychological intervention. Millions of TV and radio audiences listen and watch popular programs created in the image and likeness of Western analogues and which are not always highly intellectual, young people watch low-content films, read low-quality literature, spend a lot of time at the computer, playing aggressive and stupid games. it is a known fact that all these «achievements» of mass culture rather stupefy young people than develop their mental abilities. A hero of a new time, a new model of behaviour in new historical conditions, a new role model for today's young generation are being 
created. The main life credo of this new hero is «maximum claims with minimum effort». A person free from all traditional «forbidden complexes» has the right to desire everything immediately; the same person, who has thrown off the shackles of authoritarian mobilization (for example, public service), has the right not to be called into any service to everything that lies beyond the institution of pleasure. All these things lead to deep anomie (using the term proposed by É. Durkheim $[18$, p. 74$])$, which means the destruction of the system of norms and values. The new «hero» does not stand up to criticism in terms of morality and culture but also carries in themselves the mechanisms of social destabilization and replicates them in millions of copies. In fact, it is he who constitutes to the mass social base of all illegal practices of our time and, therefore, poses a threat to the national security of the state.

To support the national interests of Ukraine in the context of global information and psychological intervention, the state should begin to develop and implement a number of systemic humanitarian projects aimed at «soft» countering information and psychological aggression and cultivating in the population, especially in children and youth, the ability to resist humanitarian intervention of all types that is aimed at developing addictions that are unnecessary or harmful to life, including ideological, cultural, historical, political, and linguistic ones; the ability to arrange their own free time in a proper way; plan and achieve a high quality of free time use. The integration of Ukrainian education into world educational systems and the new functional and political role of education in the modern world order creates a situation where education becomes the focus of information and psychological aggression. One of the priority trends of the state's activities to support the national security of Ukraine is the protection of the national education system as a global technology for reproducing traditional consciousness, which is designed not only to solve its own tasks, but to ensure an appropriate level of immunity of the population to the information and psychological impact. National security is harmed if selfidentification, self-determination of a person as a resident of Ukraine is complicated; if education does not create new ways to respond to the processes that take place in the technological infrastructure and public consciousness; if in the structure of education there are conditions that distort or destroy the consciousness and selfconsciousness of a person; if education is improperly incorporated, embedded in the structure of society and its economic complex, and so on [19].

The convergence of issues of education and security implies a strategic view on the role of education in the development of society. In the context of information wars and information and psychological aggression, the strategic role of education in terms of protecting consciousness is determined by the fact that there is no other specialized organizational and technological reality comparable in power to the mass 
media that can create deep mechanisms of self-determination and informational and cultural immunity in the individual and public consciousness. In this context, it is difficult to overestimate the role of education in the development of critical thinking, which is necessary for a graduate of a modern university, regardless of specialty, since critical thinking allows a person to reason and act logically, taking into account both their worldview and the opinions of other people, this is the ability to refuse own prejudices as well as opinions imposed from outside. Critical thinking enables creating new ideas and seeing new opportunities, which is essential in problemsolving and decision-making. Specialists capable of critically comprehending the environment are able to consolidate traditions and experience, to influence the course and results of social and economic reforms aimed at developing the country and society. Critical thinking skills prepare the young generation for practical activity and for life in general, for the ability to predict and take into account changes in the economy, to see shifts in technology and production management. Critical thinking helps the youth change their psychology, adapt to the market economy, and develop their business skills and professional qualifications [20].

The impact of education on the security of a country is determined by the fact how much it decreases or increases the level of intellectual and volitional potential of the population compared to other countries, how much it allows the younger generation to develop high technologies, to what extent it directs young people towards solving the key acute problems they may face in the XXI century. It is important to trace whether education creates a «deep patriotism» built into the mind by means of traditions and culture or it brings up potential emigrants who, even if they do not go abroad themselves, might orient their children to select a similar life perspective. The role of today's education in the process of integration-disintegration of the country is significant, therefore, it is essential to correlate the concepts and programs of national schools (Tatar, Jewish, Hungarian and so on), regional programs for the development of education and create a single concept of education. It is important to know whether education ensures the formation of self-identification of the residents of Ukraine as Ukrainian citizens since the forms of internationalized, cosmopolitan education that are being developed at the present stage make this self-identification inessential and unnecessary. The question also arises to what extent secondary and higher professional education enable attracting the younger generation to the modern economic life of the country, to productive forms of highly effective well-paid work, because education separated from the realities of the market economy creates conditions for the criminalization of youth.

Understanding the above issues supposes answering whether it is possible to speak about building a sustainable and efficient security system for the country. 
Conclusions of the research. Education, in addition to solving its internal important task of developing the intellect and will of the nation, is directly related to state-building processes, the country's defence and reforms in the army, national security, the harmonization of national relations within a unified state space, the health of citizens, economic transformations and industrial development, breakthrough projects of the XXI century. On the basis of educational policy that has been built properly, a completely different turn of economic reforms is possible when educated people are not separated from transformations but, on the contrary, are active builders of a new market economy.

The national strategic doctrine in the field of education should direct the state policy towards the priority development of the educational sphere. Education should become the foundation of the future well-being and national security of the country, taking into account that the education system can actively affect the development of material and spiritual production; forms the main force of society - direct workers; affects the processes of changing the social structure; is the most important means to transfer to young people the moral values developed by their predecessors; forms the political views of people and imparts the initial skills of social activity; gives them the foundations of political and legal culture.

The quality of education influences significantly the fact whether civil peace is guaranteed to society, the right to have own convictions is ensured to every person who receives an education, and national security is provided to the country. Supporting the national security of Ukraine directly depends on the educational background of the country's youth in the XXI century, what are their moral and political ideals, social values, the level of general culture, and professional training.

\section{REFERENCES}

1. Panfilov, O. Yu. (Ed.) (2012). Osvitno-kulturnyi prostir Ukrainy: filosofski, istorychni, kulturolohichni abrysy. Monohrafiia. Kharkiv : Maidan [in Ukrainian].

2. Dzoban, O. P. (Ed.) (2021). Natsionalna bezpeka: svitohliadni ta teoretykometodolohichni zasady: monohrafiia. Kharkiv: Pravo [in Ukrainian].

3. Trebin, M. P. (2017). Osvita v umovakh hlobalizatsii. Materialy III Mizhnarodnoi naukovoi konferentsii «Studentska molod v umovakh hlobalizatsii» (m. Dnipro, 21 kvitnia 2017 r.) / vidp. za vypusk profesor V. V. Kryvoshein. Dnipropetrovsk: Vydavnytstvo «Hrani» [in Ukrainian].

4. Platon, \& Aristotel' (2002). Pajdejja: Voshozhdenie k doblesti /; [Sost., otv. red., avt. vvod. st. i primech. G. B. Kornetov]. Moskva: Izd-vo URAO [in Russian].

5. Huntington, S. (2002). The Clash of Civilizations and the Remaking of World Order. London: Free Press. 
6. Gessen, S. I. (1995). Osnovyi pedagogiki. Vvedenie v prikladnuyu filosofiyu / otv. red. i sost. P. V. Alekseev. Moskva: Shkola-Press [in Russian].

7. Lanovenko, O. P. (Ed.) (2004). XXI vek: mir mezhdu proshlyim i buduschim. Kultura kak sistemoobrazuyuschiy faktor mezhdunarodnoy $i$ natsionalnoy bezopasnosti : monografiya. Kiev: Stilos [in Russian].

8. Podoliakina, O. V. (2019). Dopovidi rymskoho klubu yak zmistova i tsinnisna osnova dlia suchasnoi osvity. Naukovyi visnyk. Seriia «Filosofiia»-Scientific Bulletin. Philosophy Series. Kharkiv: KhNPU, 52 (I). 31-43 [in Ukrainian].

9. Kremen, V. H. (Ed.) (2016). Natsionalna dopovid pro stan i perspektyvy rozvytku osvity $v$ Ukraini / Nats. akad. ped. nauk Ukrainy. Kyiv: Pedahohichna dumka [in Ukrainian].

10. Pashkov, A. (2017). Analiz zahroz natsionalnoi bezpeky Ukrainy ta peredovyi dosvid shchodo yikh rozviazannia. Bezpeka zhyttediialnosti-Life Safety. 1. 20-25 Retrieved from http://ekmair.ukma.edu.ua/bitstream/handle/123456789/12254/Pashkov_Analiz_ zahroz_natsionalnoi.pdf?sequence $=1 \&$ isAllowed=y [in Ukrainian].

11. Kucherenko, S. Iu. (2018). Suchasnyi stan, tendentsii ta problemy rozvytku osvity v Ukraini. Ekonomichnyi visnyk universytetu. - University economic bulletin. 36(1). 51-59.

12. Coombs, P. H. (1985). The World Crisis in Education: The View from the Eighties. New York: Oxford University Press.

13. Likona, Th. (1992). Educating for Character: How Our Schools Can Teach Respect and Responsibility. New York: Bantam.

14. Andrushchenko, V. (2008). Innovatsiinyi rozvytok osvity v stratehii «ukrainskoho proryvu». Vyshcha osvita Ukrainy - Higher education in Ukraine, 2, 10-17 [in Ukrainian].

15. Lutai, V. (2001). Rukh na vyperedzhennia (Reformuvannia vyshchoi osvity na osnovistanovlennia filosofsko metodolohichnoiparadyhmy postneklasychnoi nauky). Vyshcha osvita Ukrainy - Higher education in Ukraine. 2. 33-43 [in Ukrainian].

16. Ohnev'iuk, V. O. (2003). Osvita v systemi tsinnostei staloho liudskoho rozvytku. Kyiv : Znannia Ukrainy [in Ukrainian].

17. Panfilov, O., \& Savchenko, O. (2020). The Paradigmatic Dimension of the Modern Educational Environment. The bulletin of Yaroslav Mudryi national law university. series: philosophy, philosophies of law, political science, sociology. 46(3), 220-234 [in Ukrainian].

18. Durkheim, E. (1975). On morality and society. Chicago: University of Chicago Press.

19. Petko, L. V. (2017). Vyklyky XXI stolittia dlia osvitnoho prostoru Ukrainy. Naukovi pratsi [Chornomorskoho derzhavnoho universytetu imeni Petra Mohyly kompleksu «Kyievo-Mohylianska akademiia»]. Seriia: Pedahohika. - Scientific works [Petro Mohyla Black Sea State University of the Kyiv-Mohyla Academy complex]. Series: Pedagogy. Mykolaiv: Vyd-vo ChNU imeni Petra Mohyly, 303(291), 10-14 [in Ukrainian].

20. Paul, R., \& Elder, L. (2019). Critical Thinking: Tools for Taking Charge of Your Learning and Your Life. Boston: Pearson. 
Панфілов Олександр Юрійович, доктор філософських наук, професор, професор кафедри соціології та політології Національного юридичного університету імені Ярослава Мудрого, м. Харків, Україна

Савченко Ольга Олександрівна, кандидат філософських наук, доцент, професор кафедри іноземних мов Харківського національного університету Повітряних Сил імені Івана Кожедуба, м. Харків, Україна

\section{ОСВІТА ЯК ЧИННИК ЗАБЕЗПЕЧЕННЯ НАЦІОНАЛЬНОЇ БЕЗПЕКИ ДЕРЖАВИ}

Постановка проблеми. Дослідники проблем начіональної безпеки зазначають, що рівень розвитку освіти є найважливішим внутрішнім показником національної безпеки, оскільки саме освіта забезпечує можливість доступу до знань та участь усіх членів суспільства у створенні духовних иінностей $i$ засвоснні досягнень культури.

Аналіз публікацій з даної теми свідчить про всезростаюче усвідомлення того факту, що національна безпека і освіта взаємозалежні одна з одною. Проблеми наиіональної безпеки в їі різних аспектах достатньо трунтовно розроблені в праиях багатьох авторів. Серед них, зокрема, В. Абрамов, В. Горбулін, О. Власюк, В. Горовенко, А. Дацюк, О. Дзьобань, В. Мандрагеля, Р. Марутян, Ю. Мельник, Б. Парахонський, Г. Ситник, М. Требін та ін. Водночас проблематика ролі освіти в забезпеченні національної безпеки держави залишається розробленою недостатньо. Бракує розуміння ролі та місия освіти в системі національної безпеки, значення освіти для забезпечення начіональної безпеки України.

Мета статmі. У даній статті здійснено спробу розкриття ролі освіти в забезпеченні національної безпеки держави.

Виклад основного матеріалу. У статті наголошується, що хоча начіональну безпеку не можна забезпечити лише засобами освітньої політики, але й неможливо гарантувати поза простором освіти. Роль освіти на сучасному етапі розвитку країни визначається завданнями перетворення України в демократичне суспільство, у правову державу, державу з ринковою економікою, завданнями подолання небезпеки відставання України від світових тендениій економічного і суспільного розвитку. У иъьому зв'язку освіта повинна ввійти до складу основних пріоритетів наиіональної безпеки.

Розкрито, щзо з метою забезпечення начіональних інтересів України в умовах глобального інформаиійно-психологічного втручання держава повинна приступити до розробки і здійснення низки системних гуманітарних проектів, орієнтованих на «м'яке» відображення інформаційно-психологічної агресії і виховання в населення, насамперед у дітей і молоді, здатності протистояти гуманітарним утручанням інтервенціям усіх типів, спрямованим на організацію непотрібної або шкідливої для життя залежності, у тому числі ідеологічної, культурно-історичної, політичної 
і мовної, уміння правильно організовувати власний вільний час, планувати і досягати високої якості використання вільного часу. Одним із пріоритетних напрямів діяльності держави щодо забезпечення начіональної безпеки України є захист наиіональної системи освіти як глобальної технології відтворення традиційної свідомості, щуо поряд із тим, що вона вирішує свої власні завдання, покликана забезпечувати належний рівень стійкості населення країни до інформаційно-психологічного впливу. Національній безпещі завдається шкода, якщо ускладнюється самоідентифікація, самовизначення людини як жителя України, якщо освіта не формує нові способи реагування на прочеси, щзо відбуваються в технологічній інфраструктурі і суспільній свідомості, якщо в структурі освіти є умови, щуо спотворюють або руйнують свідомість і самосвідомість людини, якщо освіту невірно інкорпоровано, умонтовано в структуру суспільства і його господарського комплексу. Вплив освіти на безпеку країни визначається тим, якою мірою вона знижує або підвищує рівень інтелектуального і вольового потенціалу населення порівняно з іншими країнами, як вона забезпечує освоєння підростаючим поколінням високих технологій, якою мірою орієнтує молодих людей на вирішення ключових найгостріших проблем, з якими вони зустрінуться в XXI cm.

Висновки. Забезпечення начіональної безпеки України прямо залежить від того, з якою освітньою підготовкою житиме молодь країни в XXI cm., якими будуть ї̈ моральні і політичні ідеали, сочіальні иінності, рівень загальної культури і професійної підготовки. Освіта має здатність активно впливати на розвиток матеріального і духовного виробництва; формує основну силу суспільства - працівників виробництва; впливає на процеси зміни соціальної структури; є найважливішим засобом передачі молоді моральних цінностей, вироблених ї̈ попередниками; формує політичні погляди людей і прищеплює початкові навички суспільної діяльності, основи політичної і правової культури.

Ключові слова: начіональна безпека, начія, освіта, освітня політика, інтелектуальний потенціал нації.

Панфилов Александр Юрьевич, доктор философских наук, профессор, профессор кафедры социологии и политологии Национального юридического университета имени Ярослава Мудрого, г. Харьков, Украина

Савченко Ольга Александровна, кандидат философских наук, доцент, профессор кафедры иностранных языков Харьковского национального университета Воздушных Сил имени Ивана Кожедуба, г. Харьков, Украина

\section{ОБРАЗОВАНИЕ КАК ФАКТОР ОБЕСПЕЧЕНИЯ НАЦИОНАЛЬНОЙ БЕЗОПАСНОСТИ ГОСУДАРСТВА}

В статье раскрыта роль образования в обеспечении национальной безопасности государства. Обосновывается, что начиональная безопасность значительно 
зависит от состояния образования, поскольку последняя выполняет важнейшие для общества задачи - это подготовка элиты общества, управленческого персонала и высококвалифицированных спечиалистов во всех отраслях экономики, влияет на изменения в социальной структуре общества, формирует политические взгляды молодежси. Проанализирована роль образования в формировании критического мышления молодежи, что особенно актуально в условиях информационной войныл.

Ключевые слова: национальная безопасность, нация, образование, образовательная политика, интеллектуальный потенциал нации.

$\operatorname{soc}$ 